\title{
In vitro antibiotic susceptibilities of ocular bacteria isolates from the cornea and conjunctiva to moxifloxacin, gatifloxacin and other fluoroquinolones
}

\author{
Testes de sensibilidade antimicrobiana de bactérias isoladas da córnea e da \\ conjuntiva à moxifloxacina, gatifloxacina e outras fluoroquinolonas
}

\author{
Ana Luisa Höfling'-Lima ${ }^{1}$ \\ Rubens Belfort $\mathbf{J r}^{1}$ \\ Cecília Tobias Aguiar Moeller ${ }^{2}$ \\ Bruno Castelo Branco ${ }^{3}$ \\ Luciene Barbosa de Sousa ${ }^{4}$ \\ Denise de Freitas ${ }^{5}$
}

\begin{tabular}{l} 
ABSTRACT \\
\hline Purpose: To assess and compare the in vitro susceptibility of ocular \\
bacterial isolates to fluoroquinolones, including moxifloxacin and gatiflo- \\
xacin. Methods: A total of 154 bacterial ocular isolates from keratitis and \\
conjunctivitis were tested for sensitivity to the studied antibiotics, using \\
the disk diffusion method. Results: Of the 51 corneal isolates, 46 (90.2\%) \\
were sensitive to ciprofloxacin, 45 ( $88.2 \%)$ to ofloxacin and 41 (80.4\%) to \\
lomefloxacin. All corneal isolates were sensitive to moxifloxacin and \\
gatifloxacin. Of the 103 bacterial conjunctival isolates, 101 (98.1\%) and 103 \\
(100\%) were sensitive to gatifloxacin and moxifloxacin, respectively. Two \\
strains of Streptococcus sp viridans group were resistant to gatifloxacin. \\
A totalof 82 (79.6\%) specimens were sensitive to lomefloxacin, 89 (86.4\%) \\
and96(93.2\%) to ciprofloxacin and ofloxacin, respectively. Conclusions: \\
Fourth generation fluoroquinolones, herein exemplified by moxifloxacin \\
and gatifloxacin, seem to be more effective than previous generation \\
fluoroquinolones against frequently encountered organisms isolated from \\
patients with bacterial keratitis and conjunctivitis.
\end{tabular}

Keywords: Quinolones; Drug resistance, microbial; Eye infections, bacterial; Microbial sensitivity tests; Cornea/microbiology; Conjunctiva/microbiology

\section{INTRODUCTION}

Ocular infections such as bacterial keratitis, conjunctivitis, and endophthalmitis may represent a serious ocular problem with significant sightthreatening consequences if aggressive, appropriate therapy is not promptly instituted ${ }^{(1-5)}$.

To minimize visual loss due to ocular infection, diagnosis has relied on microbiology. Initial treatment with broad spectrum antibiotics is based on the clinical picture ${ }^{(1-4)}$, known pathogens and antibiotic sensitivities in a given region ${ }^{(2,5)}$.

For several years, fortified cephalosporins and aminoglycosides have been used as first choice treatment for infectious keratitis. Problems associated with topical fortified antibiotics such as local toxicity, stability, cost, need for refrigeration and the emergence of antibiotic-resistant organisms have prompted interest in the search for therapeutic alternatives ${ }^{(1,3,5-7)}$.

The fluoroquinolones used as a single commercially available drug, introduced for topical ophthalmic use in the mid- $80 \mathrm{~s}$, contributed to minimi- 
ze all those problems associated with topical fortified antibiotics and are also an alternative treatment combined with fortified topical antibiotic in severe cases $^{(3-6,-8-10)}$. This class of antibiotic provides a broad-spectrum coverage against most aerobic gram-negative and gram-positive bacteria and against some anaerobic species ${ }^{(8,10-12)}$. In addition, low toxicity, bactericidal effect, safety, good ocular penetration, and easy availability have made fluoroquinolones a good choice to treat ocular infections $\mathbf{s}^{(2,9,12)}$.

Several clinical studies have demonstrated the efficacy of fluoroquinolones in treating bacterial keratitis and conjuncti$\operatorname{vitis}^{(1,4,7,9,11-14)}$. The first fluoroquinolone antibiotics formulated for topical ophthalmic drops were ciprofloxacin, norfloxacin and ofloxacin ${ }^{(6-7,9,12)}$. However, emerging resistance to fluoroquinolones and untoward effects associated with their use, such as crystalline corneal deposits, reinforcing the need to modify some structures of this class of antibiotics ${ }^{(2,4,6,10,13)}$. New generations of fluoroquinolones, such as gatifloxacin and moxifloxacin, have been introduced to treat infections caused by organisms resistant to the previous therapy ${ }^{(14-16)}$.

Fourth generation fluoroquinolones possess an 8-methoxyside chain, which may be responsible for their enhanced activity against gram-positive, atypical pathogens and broadspectrum coverage against gram-negative organisms. They were primarily developed for the treatment of systemic infections such as pneumonia, and were also tested in ocular isolates in several studies ${ }^{(14,17-18)}$.

The study of oral administration of moxifloxacin or gatifloxacin has made it possible to show therapeutic concentrations in the aqueous humor ${ }^{(17-18)}$. Studies performed to analyze in vitro susceptibilities of these new fourth generation fluoroquinolones show an activity spectrum that appropriately encompasses the bacterial species most frequently involved in various causes of ocular infections $\mathbf{s}^{(14-17,19-21)}$.

The purpose of the present study was to assess in vitro susceptibility of ocular bacterial isolates from conjunctiva and cornea to moxifloxacin, gatifloxacin, and compare it to the previous fluoroquinolone generation, lomefloxacin, ciprofloxacin, and ofloxacin. All tested microorganisms were isolated from a population not exposed to fourth generation fluoroquinolones.

\section{METHODS}

We submitted to antibiotic susceptibility tests bacteria isolated from patients with keratitis and conjunctivitis, examined between July and November 2002 at the External Diseases Laboratory at the Federal University of São Paulo, Brazil.

Material obtained from infected areas was cultured on solid (blood, chocolate, Sabouraud's, and nonnutrient agar) and liquid media, (brain-heart infusion, and thioglycolate broth). The laboratorial diagnosis was considered positive when the same microorganism was observed on two or more media, when there was confluent growth at the site of inoculation on one solid media, or also when growth in one medium was evidenced by consistent direct microscopy findings.

All isolates were subjected to in vitro antimicrobial susceptibility testing against moxifloxacin, gatifloxacin, lomefloxacin, ciprofloxacin and ofloxacin, using the Kirby-Bauer disk diffusion method. The reading was performed by measuring the diameter of the inhibiting zone around the disk, in agreement with the National Committee for Clinical Laboratory Standards (NCCLS) ${ }^{(22)}$ criteria for all antibiotics, with one of three resulting grades: resistant, intermediately sensitive, or susceptible (Table 1).

\section{RESULTS}

A total of 154 ocular pathogens from 94 patients with culture-proven bacterial keratitis or conjunctivitis were isolated. Susceptibility tests to the trial antibiotics were performed.

Of the 51 corneal isolates subjected to susceptibility tests, $33(64.7 \%)$ were gram-positive cocci and $18(35.3 \%)$ were gramnegative bacilli. The most common microorganisms in decreasing order of frequency were coagulase-negative Staphylococcus, Pseudomonas sp, Staphylococcus aureus and Streptococcus pneumoniae (Table 2).

Of the 103 conjunctival isolates submitted to susceptibility tests, $87(84.5 \%)$ were gram-positive cocci and $16(15.5 \%)$ were gram-negative bacilli. The most common isolates in decreasing order of frequency were: coagulase-negative Staphy-

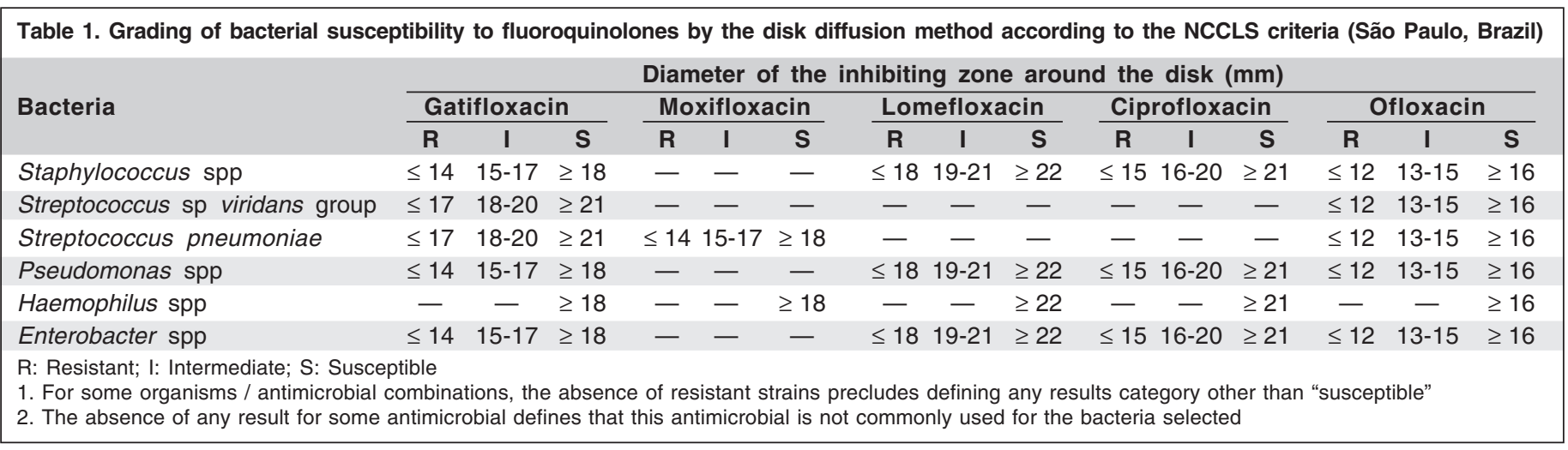


Table 2. In vitro susceptibility of corneal bacterial isolated to antimicrobial agents

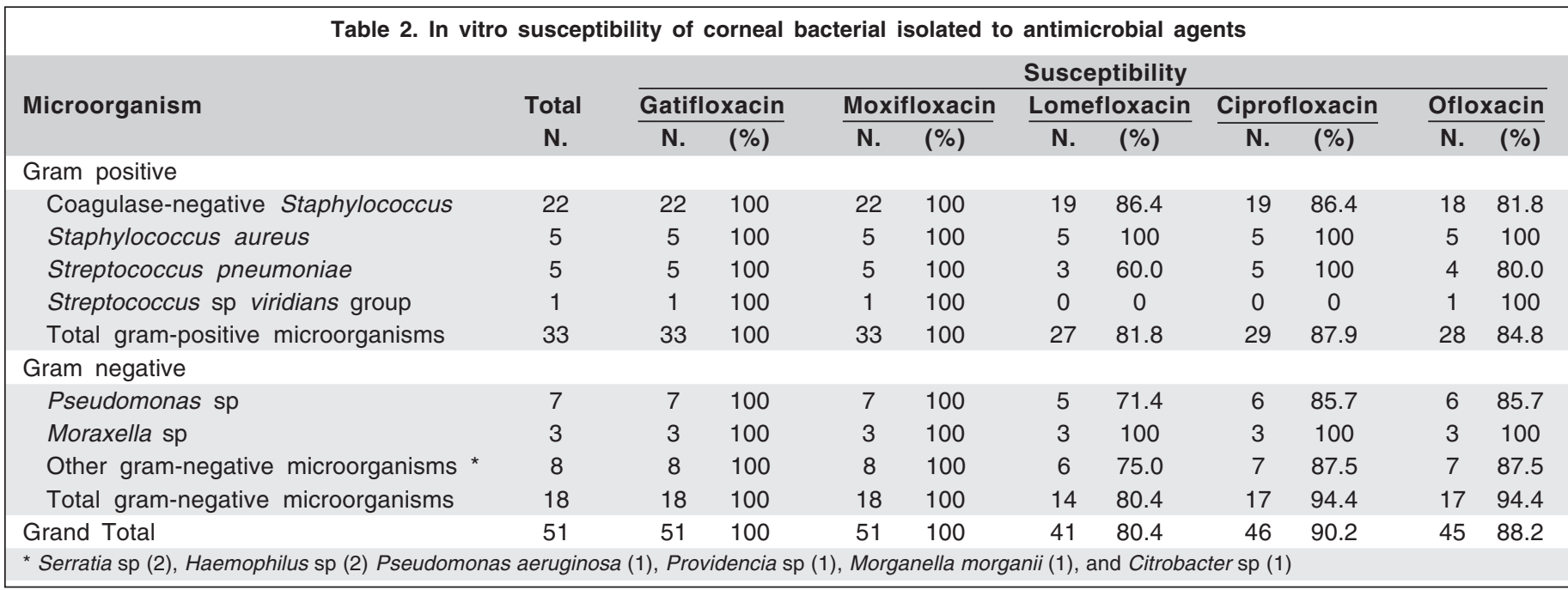

lococcus, Staphylococcus aureus, Haemophilus sp and Streptococcus sp viridans group (Table 3).

Overall susceptibilities of ciprofloxacin, ofloxacin and lomefloxacin to microorganisms isolated from keratitis were, $90.2 \%, 88.2 \%$ and $80.4 \%$, respectively. Moxifloxacin and gatifloxacin were effective against all corneal isolates.

The same analysis performed of the conjunctival pathogens revealed overall susceptibilities of ciprofloxacin, ofloxacin and lomefloxacin of $86.4 \%, 93.2 \%$ and $79.6 \%$, respectively. Gatifloxacin and moxifloxacin showed antimicrobial sensitivities of $98.1 \%$ and $100 \%$, respectively. Resistance to gatifloxacin was observed in two strains of Streptococcus sp viridans group.

\section{DISCUSSION}

In our study, the fourth generation fluoroquinolones appear to cover second-generation resistance among most Staphylo- coccal species, S. viridans, and Pseudomonas. This finding is supported by other studies with bacterial isolates from intraocular infections ${ }^{(14-16,19)}$. These new fluoroquinolones show great promise for treating ocular infections and may be an alternative to prevent postsurgical endophthalmitis in special cases.

An experimental laboratory investigation revealed that both moxifloxacin and gatifloxacin were more potent than the second and third generation fluoroquinolones against grampositive bacteria and equally potent against gram-negative bacteria $^{(14)}$. These results are in accordance with our study, with the exception that both moxifloxacin and gatifloxacin also displayed clearly improved activity against gram-negative bacilli of ocular isolates.

The observed variation in susceptibility of Streptococcus $\mathrm{sp}$ viridans group to one of the fourth generation fluoroquinolones, in this study, may reflect established differences in the serum standards for each of the fluoroquinolones. Since drug levels attainable in the cornea are considerably higher than those in

Table 3. In vitro susceptibility of conjunctival bacterial isolated to antimicrobial agents

\begin{tabular}{|c|c|c|c|c|c|c|c|c|c|c|c|}
\hline \multirow{3}{*}{ Microorganism } & \multirow{3}{*}{$\begin{array}{c}\text { Total } \\
\mathrm{N} .\end{array}$} & \multicolumn{10}{|c|}{ Susceptibility } \\
\hline & & \multicolumn{2}{|c|}{ Gatifloxacin } & \multicolumn{2}{|c|}{ Moxifloxacin } & \multicolumn{2}{|c|}{ Lomefloxacin } & \multicolumn{2}{|c|}{ Ciprofloxacin } & \multicolumn{2}{|c|}{ Ofloxacin } \\
\hline & & N. & $(\%)$ & $\mathrm{N}$. & $\overline{(\%)}$ & $\mathrm{N}$. & $(\%)$ & $\mathrm{N}$. & $(\%)$ & $\mathbf{N}$. & $(\%)$ \\
\hline Coagulase-negative Staphylococcus & 55 & 55 & 100 & 55 & 100 & 50 & 90.9 & 50 & 90.9 & 52 & 94.5 \\
\hline Staphylococcus aureus & 22 & 22 & 100 & 22 & 100 & 14 & 63.6 & 19 & 86.4 & 22 & 100 \\
\hline Streptococcus sp viridians group & 8 & 6 & 75.0 & 8 & 100 & 3 & 37.5 & 2 & 25.0 & 6 & 75.0 \\
\hline Total gram-positive microorganisms & 87 & 85 & 97.7 & 87 & 100 & 69 & 79.3 & 73 & 83.9 & 82 & 94.3 \\
\hline \multicolumn{12}{|l|}{ Gram negative } \\
\hline Haemophilus sp & 10 & 10 & 100 & 10 & 100 & 8 & 80.0 & 10 & 100 & 8 & 80.0 \\
\hline Serratia sp & 2 & 2 & 100 & 2 & 100 & 2 & 100 & 2 & 100 & 2 & 100 \\
\hline Other gram-negative microorganisms * & 4 & 4 & 100 & 4 & 100 & 3 & 75.0 & 4 & 100 & 4 & 100 \\
\hline Total gram-negative microorganisms & 16 & 16 & 100 & 16 & 100 & 13 & 81.3 & 16 & 100 & 14 & 87.5 \\
\hline
\end{tabular}


serum, disc diffusion methods tend to overestimate resistance for ocular pathogens, from a clinical standpoint. However, results encountered may reflect a plasmid-mediated resistance, once the fourth generation fluoroquinolones were developed to resist spontaneous mutations, and generally two genetic mutations are required for changes in antibiotic susceptibility to occur with fourth generation fluoroquinolones ${ }^{(14)}$.

Initial results from this in vitro study of corneal and conjunctival bacterial isolates show forthcoming advantage of fourth generation fluoroquinolones over second generation as demonstrated with the broad spectrum activity observed for gram-positive cocci, gram-negative bacilli and anaerobic microorganisms ${ }^{(15-18,23)}$.

One of the limitations of using in vitro antimicrobial susceptibility testing as a surrogate for in vivo effectiveness is that although a favorable clinical result is not guaranteed, it does provide an indication of the potential susceptibility of the microorganism in vivo. Ongoing therapy still should be guided by assessment of the patient's clinical response.

\section{CONCLUSION}

As recommended the key parameter to consider in the comparison of antibiotic potency is the MIC value; therefore, further tests are necessary to complete this evaluation.

A new possibility for treating ocular infections and preventing postsurgical endophthalmitis considering cost and benefit must be analyzed. In order to avoid development of resistance, the use has to be analyzed considering that second generation fluoroquinolones still remain effective against most ocular bacterial isolates.

\section{RESUMO}

Objetivos: Conhecer e comparar a susceptibilidade in vitro de bactérias isoladas do olho à fluoroquinolonas, incluindo moxifloxacina e gatifloxacina. Métodos: Um total de 154 bactérias isoladas de ceratites e conjuntivites foram submetidas a testes de sensibilidade antimicrobiana aos antibióticos usando o método de difusão em disco. Resultados: Das 51 bactérias isoladas da córnea, $46(90,2 \%)$ foram sensíveis a ciprofloxacina, $45(88,2 \%)$ a ofloxacina e $41(80,4 \%)$ a lomefloxacina. Todas as bactérias isoladas da córnea foram sensíveis a moxifloxacina e a gatifloxacina. Das 103 bactérias isoladas da conjuntiva $101(98,1 \%)$ e $103(100 \%)$ foram sensíveis a gatifloxacina e moxifloxacina, respectivamente. Duas cepas de Streptococcus sp do grupo viridans mostraram-se resistentes à gatifloxacina. Um total de $82(79,6 \%)$ espécimes foi sensível a lomefloxacina, $89(86,4 \%)$ e $96(93,2 \%)$ a ciprofloxacina e ofloxacina, respectivamente. Conclusões: As quinolonas de $4^{\mathfrak{a}}$ geração, aqui exemplificadas pela moxifloxacina e gatifloxacina, apresentam eficácia antimicrobiana maior do que a ciprofloxacina, ofloxacina e lomefloxacina contra os organismos freqüentemente isolados em pacientes com infecções bacterianas da córnea e da conjuntiva.
Descritores: Quinolonas; Resistência microbianas a drogas; Infecções oculares bacterianas; Testes de sensibilidade microbiana; Córnea/microbiologia; Conjuntiva/microbiologia

\section{REFERENCES}

1. Cokingtin CD, Hyndiuk RA. Insights from experimental data on ciprofloxacin in the treatment of bacterial keratitis and ocular infections. Am J Ophthalmol. 1991;112(4 Suppl):25S-8.

2. Limberg MB. A review of bacterial keratitis and bacterial conjunctivitis. Am J Ophthalmol. 1991;112(Suppl. 4):2S-9.

3. Garg P, Sharma S, Rao GN. Ciprofloxacin-resistant Pseudomonas keratitis. Ophthalmology. 1999;106(7):1319-23.

4. Leibowitz HM. Clinical evaluation of ciprofloxacin $0.3 \%$ ophthalmic solution for treatment of bacterial keratitis. Am J Ophthalmol. 1991;112(Suppl. 4):34S-47.

5. Goldstein MH, Kowalski RP, Gordon YJ. Emerging fluoroquinolone resistance in bacterial keratitis: a 5-year review. Ophthalmology. 1999;106(7):1313-8.

6. Castillo A, Benitez del Castillo JM, Toledano N, Diaz-Valle D, Sayagues O, Garcia-Sanches J. Deposits of topical norfloxacin in the treatment of bacterial keratitis. Cornea. 1997;16(4):420-3.

7. Bower KS, Kowalski RP, Gordon YJ. Fluoroquinolones in the treatment of bacterial keratitis. Am J Ophthalmol. 1996;121(6):712-5.

8. Ofloxacin monotherapy for the primary treatment of microbial keratitis: a double-masked, randomized, controlled trial with conventional dual therapy. The Ofloxacin Study Group. Ophthalmology. 1997;104(11):1902-9.

9. Ogawa GS, Hyndiuk RA. The fluoroquinolones: new antibiotics in ophthalmology. Int Ophthalmol Clin. 1993;33(4):59-68

10. Serdarevic ON. Role of the fluoroquinolones in ophthalmology. Int Ophthalmol Clin. 1993;33(1):163-78.

11. O'Brien TP, Maguire MG, Fink NE, Alfonso E; McDonnell P. Efficacy of ofloxacin vs cefazolin and tobramycin in the therapy for bacterial keratitis. Report from the Bacterial Keratitis Study Research Group. Arch Ophthalmol. 1995;113(10): 1257-65.

12. Donnenfeld ED, Schrier A, Perry HD, Auulicino T, Gombert ME, Snyder R. Penetration of topically applied ciprofloxacin, norfloxacin, and ofloxacin into the aqueous humor. Ophthalmology. 1994;101(5):902-5.

13. Kunimoto DY, Sharma S, Garg P, Rao GN. In vitro susceptibility of bacterial keratitis pathogens to ciprofloxacin. Emerging resistance. Ophthalmology. 1999;106(1):80-5.

14. Mather R, Karenchak LM, Romanowski EG, Kowalski RP. Fourth generation fluoroquinolones: new weapons in the arsenal of ophthalmic antibiotics. Am J Ophthalmol. 2002;133(4):463-6.

15. Kowalski RP, Karenchak LM, Romanowski EG, Mah FS, Ritterband DC, Gordon YJ. Will the fourth-generation fluoroquinolones provide any advantage in the future treatment of bacterial keratitis? In: 36th Annual Meeting: Ocular Microbiology and Immunology Group (OMIG); 2002; Orlando, FL; 2002. Available from: http://eyemicrobiology.upmc.com/2002Abstracts/2002Abs1.htm

16. Monica M, Jensen HG. Susceptibility of ocular isolated to gatifloxacin and other fluoroquinolones. In: 36th Annual Meeting: Ocular Microbiology and Immunology Group (OMIG); 2002; Orlando, FL; 2002. Available from: http://eyemicrobiology.upmc.com/2002Abstracts/2002Abs3.htm

17. Hariprasad SM, Mieler WF, Holz ER. Vitreous and aqueous penetration of orally administered gatifloxacin in humans. Arch Ophthalmol. 2003;121(3):345-50.

18. Garcia-Saenz MC, Arias-Puente A, Fresnadillo-Martinez MJ, arrasco-Font C. Human aqueous humor levels of oral ciprofloxacin, levofloxacin, and moxifloxacin. J Cataract Refract Surg. 2001;27(12):1969-74.

19. Balfour JA, Wiseman LR. Moxifloxacin. Drugs. 1999;57(3):363-73; discussion p. 374 .

20. Shah M, Ritterband DC, Dingley A, Koplin R, Seedor J. Will the new generation of fluoroquinolone antibiotics become the antimicrobials of choice in endophthalmitis prophylaxis? In: 36th Annual Meeting: Ocular Microbiology and Immunology Group (OMIG); 2002; Orlando, FL; 2002. Available from: http://eyemicrobiology.upmc.com/2002Abstracts/2002Abs $12 . \mathrm{htm}$

21. Myung-Jin J, Aliprandis E, Terrence P, O'Brien TP. Comparative efficacy of topical gatifloxacin, a new fluoroquinolone, versus topical ciprofloxacin, penicillin $\mathrm{G}$ and tobramycin in the treatment of experimental S. pneumoniae and P. aeruginosa keratitis in rabbits. In: 36th Annual Meeting: Ocular Microbiology and Immunology Group (OMIG); 2002; Orlando, FL; 2002. Available from: http://eyemicrobiology.upmc.com/2002Abstracts/2002Abs2.htm

22. NCCL. Methods for dilution antimicrobials susceptibility tests for bacteria that grow aerobically. Villanova, Pennsylvania: National Committee for Clinical Laboratory Standards; 2000.

23. Ednie LM, Jacobs MR, Appelbaum PC. Activities of gatifloxacin compared to those of seven other agents against anaerobic organisms. Antimicrob Agents Chemother. 1998;42(9):2459-62. 